\title{
EXPLORING THE INFLUENCE OF CITIZEN JOURNALISM CONTENT ON THE MALAYSIAN POLITICAL LANDSCAPE
}

\section{Nuurrianti Jalli}

Faculty of Communication and Media Studies, Universiti Teknologi MARA, Selangor, MALAYSIA

Email: nuurrianti@gmail.com

Published online: 30 April 2020

To cite this article: Nuurrianti Jalli. 2020. Exploring the influence of citizen journalism content on the Malaysian political landscape. Kajian Malaysia 38(1): 67-88. https://doi.org/10.21315/ $\mathrm{km} 2020.38 .1 .4$

To link to this article: https://doi.org/10.21315/km2020.38.1.4

\begin{abstract}
Across the world, the use of the internet has impacted citizenship and governance which in some cases has resulted in the modification of political landscapes. Events such as the overthrow of regimes in the Middle-East during Arab Spring to the latest election upset in Malaysia in 2018, have proven the potential of new media platforms as media of change. Diverse media content generated by the public, including citizen-generated news, is shared across virtual space. Before the advent of the internet, journalism was practiced exclusively by trained journalists. These days, however, everyone has access to the tools to produce news on his or her own. This type of journalism, described in this study as citizen journalism, has changed the dynamic of news-sharing. This article seeks to explore how citizen journalism content has influenced the Malaysian political landscape. In 2016, two years before the shocking election upset in Malaysia, eight informants were interviewed for this study. The interviews were conducted in Malaysia and the United Kingdom. Despite the abundance of content on the internet generated by citizen journalists, it is believed that Malaysians in general still rely heavily on materials produced by professionals. Based on the respondents' responses, citizen journalism does have influence over the political landscape and plays a part in shaping public opinion.
\end{abstract}

Keywords: Malaysia, citizen journalism, political landscape, citizen news, new media, Internet, media literacy, fake news, democracy, political participation 


\section{INTRODUCTION}

Malaysia, one of the leading developing countries in the Malay Archipelago, achieved independence from its British colonial masters in 1957. Since then, the leading coalition, Barisan Nasional has been the primary political coalition in the country. Throughout the decades of Barisan Nasional's governance, the coalition has been criticised by many as a pseudo-democracy at best even though Malaysia has been recognised in the world as a democratic state in the eyes of the world (Case 2004a; 2004b; Volpi 2004; Slater 2003; Chin 2014). Unlike in a true democracy, however, Malaysia under Barisan Nasional has been administered through stringent laws and regulations that have limited the civil rights of the people (Thompson 1993; Weiss 2009; Freedom House 2018). Media freedom in Malaysia has been limited through the domination of ownership and strict regulations. But gradually over the years, with increased penetration of the internet in Malaysia, especially in the 2000 s, the country's political landscape has slowly changed. This can be seen in the rising number of civil society movements and the increased participation by the citizens in political discourse (Abbott 2001; Couldry and Curran 2003; Weiss 2006; Tan and Zawawi 2008). As of 2017, internet penetration in Malaysia has increased to $78.8 \%$ according to Freedom House (2018), one of the global media watchdogs.

Nevertheless, as in many developing countries, digital gaps exist in Malaysia especially an urban versus rural context. Such digital gaps also exist in media literacy among the people in general. The issue of internet speed discrepancy is prevalent between people in the city centers and people living in rural areas. For example, citizens living in Kuala Lumpur have access to high-speed personal internet service up to $1 \mathrm{Gbps}$ if they subscribe to Time Fibre internet at only RM199 per month (USD48) (TIME 2018). Alternatively, they could subscribe to Unifi, a high-speed internet service offered by one of the leading internet service providers in Malaysia, Telekom Malaysia, at $100 \mathrm{Mbps}$, for only RM79 per month (USD20) (Telekom Malaysia 2018a). In contrast, in less developed areas such as Bintangor, Sarawak, Streamyx, another Telekom Malaysia plan with a top speed of only $8 \mathrm{Mbps}$ and a hefty fee of RM160 per month (USD38.4) (Telekom Malaysia 2018b), is the only internet service available. With much slower internet speed, many people of rural areas cannot access as much content on the internet, especially when it comes to streaming media content with vast data transmission.

However, despite the gap, a growing number of Malaysians are using online platforms to create and share news content. Social media apps like Facebook, Twitter and WhatsApp among others are used to disseminate content to friends and families. In many cases, alternative news sites in Malaysia use content shared by citizen journalists to facilitate news reporting. The goal of this research is to explore the influence of citizen journalism in the Malaysian political metamorphosis 
through in-depth interviews with eight informants who are knowledgeable about media and politics in Malaysia. This research was conducted in 2016, almost two years before the Malaysian 14th General Election. Thematic analysis was done on the informants' responses to identify emerging themes from the conversation on the research topic. Unlike other online activities, citizen journalism in Malaysia has not been discussed adequately enough to help scholars understand its role in politics.

\section{CONTENT GENERATED BY CITIZEN JOURNALISTS}

For many years, journalism has been reserved for a select few with proper journalistic training (e.g., a degree in journalism or similar preparation) and appropriate resources to provide news stories to readers and audiences. It is an elite practice that many people still believe to be the most trusted way to get reliable news updates. Journalism has been defined by scholars as a practice of producing and disseminating accurate and dependable news on contemporary affairs (Kovach and Rosenstiel 1999; Schudson 2003). Before the realm of the internet, only individuals who underwent professional journalistic training were considered as journalists (Gillmor 2006). However, journalism has experienced a significant change as a result of the development of communication technologies enabling people who had never had any professional journalistic training to generate news content themselves (Channel 2010). The internet has enabled people around the world to access a wide variety of information online. This includes information on "classified" data as well as content the government has deemed "sensitive". Websites such as Wikileaks and sites run by Anonymous, a network of activists and hacktivists, provided global audiences with tremendous amounts of confidential data made available through internet technology. With the ability to locate varied content through search engines such as Google, Yahoo and Bing, users can now retrieve all sorts of information.

The internet not only provides users with easier ways to obtain information but also enables them to generate and share content with wider audiences, even across geographical boundaries (Gillmor 2006). Millions use social media sites such as Facebook, Twitter and YouTube to share content with the public. Such content varies from general reports on current issues, to online tutorials, to citizen news. The rise of citizen journalism across the world has been positively affected by the development of the telecommunication infrastructures. Citizen journalism, however, is a loosely defined term with permutations as assorted as the names it is known by - participatory journalism, guerrilla journalism and open-source journalism, among others (Jurrat 2012). Scholars like Chadha and Steiner (2015) noted this issue with citizen journalism's definition, explaining that "citizen 
journalism is a somewhat fuzzy term used in different ways by different people at different times" (p. 709). Scholars like Gillmor (2006), Reich (2008), Rosen (2008), Seneviratne (2008) and Albarado (2012) have defined citizen journalism as a type of journalistic activity carried out by individuals with no professional training.

Other scholars defined citizen journalism in a much broader context. Bowman and Willis (2003), for example, viewed citizen journalism as a kind of journalism practiced by the citizens where they are "playing an active role in the process of collecting, reporting, analyzing, and disseminating news and information" (p. 9). Bowman and Willis (2003) and other scholar (see Lieb 2009) did not specifically define citizen journalism as a practice carried out by those who never underwent journalistic training. The different interpretations among scholars elucidate the unclear definition behind the term - raising questions about whether professional journalists not in their work settings or those no longer working as journalists but contributing news to the public would be considered citizen reporters or would be consigned to a different group. However, in the context of this research, citizen journalism is defined as a type of journalistic activity carried out by individuals with no professional journalism training (Gillmor 2006; Reich 2008; Rosen 2008; Seneviratne 2008; Albarado 2012). These so-called journalists or citizen reporters create news content and share it online with their immediate friends or families and even wider audiences. One of the earliest examples of extensive use of the internet was during the World Trade Center attack on 11 September 2001, when people reported the breaking news, sharing information, pictures and videos of the attack. Individuals not present in New York used the internet to "connect to the experience by watching it in real time on TV and then posting them on forums and message boards" (Krotoski 2011). Others used the web to retrieve more information as TV was deemed unable to deliver information as "rich" as that provided by citizen journalists in the virtual domain. Sharing of citizen journalism content has become a lot easier as the popularity of social media rises across the world. Social media are the optimal platform for citizen journalism activities for several reasons. First, the user-friendly interface of social media sites such as Facebook and Twitter have made it easy for people to upload and share their content. Second, the massive number of social media users increases the possibility for citizen journalism content to reach wider audiences than do traditional media outlets. The latest statistics by Social Baker claimed that Facebook users numbered 1,280 million in 2019. According to Lee (2016), $80 \%$ of internet users had at least one Facebook account in 2016.

The third reason social media excel as a citizen journalism platform is the continuous development of communication technologies across the globe. Internet penetration is constantly increasing, with growing numbers of internet users raising the probability of an even greater amount of news content. In a country like 
Malaysia, where the media environment is tightly restricted by the government, the internet provides alternative ways for people to obtain and share information, bypassing governmental restrictions on traditional media. Users thus have total control over their content. New media platforms are used to express dissenting opinions about the government and to provide news from viewpoints different than ones produced by the government-controlled media. According to DeMers (2013), an increasing number of people have complained that the traditional media are not only "too slow" in reporting news, they side too much with the individuals in power. Deepening dissatisfaction with traditional media and availability of affordable mobile devices with constant internet connection have allowed citizen journalism to flourish (DeMers 2013).

Nevertheless, citizen journalism has been criticised. Critics have argued that there are problems concerning credibility, accountability, objectivity and authenticity (Gillmor 2006; Allan and Thorsen 2009). Credibility is one of the foremost issues. Professional journalists, who are skeptical of untrained individuals' ability to produce reliable news, have questioned how audiences can know if the news generated by these "reporters" is reliable and based on accurate information. Internet users can cloak their real identities and remain anonymous, pressing accountability as another major concern. In journalism, anonymity is seen both positively and negatively. On the positive side, anonymity provides an opportunity for whistleblowers to share confidential content to the public without jeopardising their own safety. The absence of gatekeepers in citizen journalism contributes to low-quality content (Lewis, Kaufhold and Lasorsa 2010). Gatekeeping in mass communication theory illustrates the process involved in the gathering, filtering and dissemination of news content (Beard and Olsen 1999). In the wake of online communications, the gatekeeping process in media has changed and a number of critics have asserted that the gatekeeper is often absent in citizen journalism (Singer 2006). According to Singer (2006), the internet opposes the whole gatekeeping concept - and challenges the idea that journalists or other internet users can or should limit what goes through it (p. 265). Citizen journalists can easily write and immediately publish their content without having to undergo the rigorous editing experienced by professional journalists. Furthermore, these amateurs often compete with one another (and with the professional media) in reporting the latest news, especially on social media. The impulse to be the first to publish breaking news also contributes to the production of low-quality news by citizen journalists who fail to corroborate facts or provide in-depth details. Professional journalists are concerned that news reported by citizen journalists is heavily influenced by personal opinion and bias (Phillips 2009).

Professional journalists often criticise citizen reporters for reproducing existing news instead of reporting original content. Many times, citizen journalists take content from traditional media or other sources and republish the content 
on their sites just to receive visitors' hits. Some citizen journalist blogs generate revenue from an online advertising scheme $^{1}$ based on the number of visits the website receives. The issue of authenticity of citizen journalism is related to the production of accurate news (Dredge 2014; Baker 2015). Critics have pointed out that with the absence of journalism training among citizen reporters, most of them fail to authenticate the content (like providing accurate facts) they produce.

\section{CITIZEN JOURNALISM IN MALAYSIA}

Citizen journalism content in Malaysia can be found mainly on personal blogs or websites and on social media. In the early 2000 s, before the popularity of such social media sites as Facebook and Twitter, personal websites, or blogs, were popular with internet users. Among popular blogging sites then was "Screenshots..." by Jeff Ooi. People were checking online blogs for alternative views on the political news to contrast with the content on mainstream media. The popularity of bloggers was illustrated by the election of Jeff Ooi and few other bloggers in the 2008 election (Abbott 2014). Personal blogs and websites are declining in popularity among citizen journalists who prefer to use social media platforms these days, but some citizen journalists are active on blogs and websites in Malaysia today. "Citizen Journalists Malaysia" and "Media Rakyat" (citizen media) are among the well-known sites run by citizen journalists. Both provide critical, politically related news to the public, unlike many other sites that mainly report on the entertainment industry. "Media Rakyat", for example, aims to provide diverse information on Malaysian politics as a way to improve freedom of information in the state (Media Rakyat 2017). Today, many news reports generated by citizen journalists can be found on social media sites like Facebook, Twitter, YouTube and WhatsApp. Self-created content and news reports about exciting events the bloggers experienced were shared with friends and family. Sometimes, content created by these citizen journalists was picked up by major media channels as a part of their news content for a particular day. Citizen journalism has been seen as one of the elements that influence political changes in Malaysia. Scholars claimed the two latest general elections (GE13 and GE14) were social media elections (Mohd Azizuddin 2014; Idid 2018). Political content was shared on social media platforms to instigate political conversation on politics although there were many claims that citizen reporters often circulated fake news during the election period (Idid 2018). However, other scholars have argued that both political sides (Barisan Nasional and Pakatan Harapan) used social media strategically through cyber troopers which had more significant influence during GE13 and GE14 (Hopkins 2014; Mohd Azizuddin 2018). 


\section{METHODOLOGY}

\section{In-Depth Interview}

According to Lindlof and Taylor (2017), an informant interview takes place when a participant selected for an in-depth interview is considered qualified, experienced and knowledgeable about the research topic. In-depth interviews are well-suited to assist researchers in understanding the informants' experience, knowledge and perspective (Lindlof and Taylor 2017). Interviews began on 10 April 2016 and ended on 5 October 2016; about two years before the change of the Malaysian government. Before the meetings, a brief summary of the research project and a request letter were sent to each informant seeking his/her agreement to be interviewed along with a consent form to peruse and sign. The letter stated that if the recipients agreed to participate in the research, their identities would be disclosed in the final report. After respondents agreed to be interviewed with the understanding that their identities would be revealed in the final report, the interview method, time and place were established. Four of the interviews were carried out electronically and the remaining four were conducted face-to-face with the informants.

\section{Selection of Informants}

Informants were chosen based on predetermined characteristics: (1) the informant has deep knowledge of Malaysian politics, (2) the informant is a well-known media person or is involved in the Malaysian political scene, (3) the informant has an active voice in the community and considered an opinion leader, (4) the informant has high credibility and represents a strong organisation/company/political party, and (5) the informant has a strong social background (education, career, etc.). I initially intended to interview 10 informants but had a difficulty recruiting sources with a pro-Barisan Nasional background due to the sensitivity of the subject. In contrast to the present time, in 2016 research related to Malaysian politics was a delicate subject among government officers. As one of the earliest recruiting steps, I sent an email to 15 potential interviewees all of whom are wellknown to Malaysian citizens as editors, journalists, activists or political figures. Only eight of them replied favourably. The list of informants can be found in Table 1. 
Table 1: List of informants

\begin{tabular}{|c|c|c|}
\hline No. & Name & Brief info on the informant \\
\hline 1 & $\begin{array}{l}\text { Raja Petra } \\
\text { Kamaruddin }\end{array}$ & $\begin{array}{l}\text { Interviewed on } 28 \text { April } 2017 \text {, in Manchester, United Kingdom. } \\
\text { Raja Petra Kamaruddin is a political blogger and the chief editor of } \\
\text { Malaysia Today. Some content on his site was seen as too critical } \\
\text { of the government, and he was charged under the Malaysian Penal } \\
\text { Code, the Internal Security Act (ISA) 1960, and the Sedition Act } \\
\text { 1948. }\end{array}$ \\
\hline 2 & $\begin{array}{l}\text { Clare Rewcastle } \\
\text { Brown }\end{array}$ & $\begin{array}{l}\text { Clare Rewcastle Brown was interviewed for this research on } 18 \text { April } \\
2016 \text {, in London, United Kingdom. Born in Sarawak, Malaysia, she } \\
\text { is the chief editor for Sarawak Report that first reported the 1MDB } \\
\text { scandal involving the former Prime Minister Najib Razak. }\end{array}$ \\
\hline 3 & Marina Mahathir & $\begin{array}{l}\text { Interviewed on } 28 \text { July } 2016 \text {, in Kuala Lumpur. Marina Mahathir } \\
\text { is the eldest daughter of the Prime Minister of Malaysia, Tun Dr. } \\
\text { Mahathir Mohamad. She is a sociopolitical and human rights } \\
\text { activist and a columnist. }\end{array}$ \\
\hline 4 & Fathi Aris Omar & $\begin{array}{l}\text { Interviewed on } 28 \text { July 2016, in Kuala Lumpur. Fathi Aris Omar } \\
\text { is currently the editor for Malaymail Online, and an ex-editor } \\
\text { of Malaysiakini. He had experienced being detained by the } \\
\text { former Barisan Nasional government for comments he made on } \\
\text { Malaysiakini. }\end{array}$ \\
\hline 5 & Nurul Izzah Anwar & $\begin{array}{l}\text { Interviewed electronically on } 11 \text { August 2016. Nurul Izzah Anwar, } \\
\text { daughter of the prominent political leader Anwar Ibrahim, and } \\
\text { currently the Member of Parliament, Permatang Pauh. She was the } \\
\text { Vice President of the People's Justice Party (Keadilan Rakyat) at the } \\
\text { time of the interview in } 2016 \text {. }\end{array}$ \\
\hline 6 & Lau Chak Onn & $\begin{array}{l}\text { Lau Chak Onn is the co-founder and current editor-in-chief of } \\
\text { Cilisos.my, an alternative news site providing readers with news } \\
\text { content through provocative and humorous graphics. He believes } \\
\text { in collaborative journalism, accepting content and information } \\
\text { provided by citizen journalists to be featured on the site. The } \\
\text { interview with Lau Chak Onn was conducted electronically on } \\
17 \text { August } 2016 \text {. }\end{array}$ \\
\hline 7 & Rosey Haji Yunos & $\begin{array}{l}\text { Interviewed electronically on } 18 \text { August } 2016 \text {. Rosey Haji Yunos is } \\
\text { currently the Assistant Minister for Solidarity in the Sarawak State } \\
\text { Government. At the time of the interview in 2016, she was a Barisan } \\
\text { Nasional state representative. }\end{array}$ \\
\hline 8 & Ibdillah Ishak & $\begin{array}{l}\text { Ibdillah Ishak is an exco member of the United Malays National } \\
\text { Organization (UMNO) Youth. UMNO is the leading political party } \\
\text { in the former Barisan Nasional government. The interview with } \\
\text { Ibdillah Ishak was conducted electronically on } 9 \text { October } 2016 \text {. }\end{array}$ \\
\hline
\end{tabular}




\section{DATA ANALYSIS: THEMATIC ANALYSIS}

For this research, thematic analysis was the primary analytic technique to interpret the obtained data. Thematic analysis is a research technique used to identify, analyse and report on patterns (themes) within data (Braun and Clarke 2006, 79). Often praised for its flexibility as a research method, thematic analysis provides researchers with rich and comprehensive data. Specifically, the technique involves seeking patterns across a set of data obtained from interviews, focus groups, or a range of texts to find meaning (Braun and Clarke 2006).

\section{Citizen Journalism Provides Alternative Views on Sociopolitical Issues}

This subtheme captured informants' views on the ability of citizen journalism to provide alternative views on sociopolitical issues in Malaysia. As a result of the restrictive media environment in Malaysia, introduction of the internet was seen as a possible way out of the state's close monitoring. Most of the informants agreed that the internet provided people access to a wider range of information and the technology has also assisted in the blossoming of citizen journalism. Differing from the mainstream media, where content must be approved by editors, then scrutinised by the government, online citizen journalism is not bound by any framework. ${ }^{2}$ This allows citizen journalists room to report news with less fear and to potentially provide a wider prospect of sociopolitical events happening in the country. As Nurul Izzah Anwar said,

Citizen journalism is the most decentralised form of journalism, and by that virtue the most organic and unprocessed. Citizen journalists are less afraid to express their opinions, and show their biases, if any. In some ways, they are the very core of free media.

Fathi Faris Omar emphasised that introduction of the internet has expanded the public sphere for political discussion. He said,

It is undeniable that the internet has expanded what Jurgen Habermas called the public sphere, opening pathways for the people to participate in critical discourse with a safety cloak (anonymity). The liberating features of the internet allow people to generate various content unlike ever before (pre-internet). The presence of citizen journalists challenges the credibility of reports produced by people from the mainstream media. Alternative perspectives of events happening in the country, especially in politics, and the availability of such content is very much needed to allow the people to make better decisions on political issues. 
Rosey Haji Yunos shared that opinion. She said, "It (citizen journalism) portrays the real truth without fear or favour (having to side with certain parties; media owners)". Other informants noted that the existence of citizen journalism provided opportunity for the mainstream media channels to reevaluate their delivering style. The government should use the constant criticism of the mainstream media to improve it instead of continuously ignoring the comments.

Nurul Izzah Anwar commented on how citizen journalism opens the way for multidirectional communication between content producers and audiences. She said, "Despite being accountable only to their personal capacity, it (citizen journalism) enriches the media space for interaction with citizens". The establishment of rapport between citizen journalists and their audiences through communication and feedback even leads to formation of loyal followers. Loyal followers also tend to follow the political leaning of the opinion leader. "In fact, some selected citizen journalists have attracted a considerable following rendering them sources of influence that affect the current status quo", said Nurul Izzah Anwar. The same view is shared by Fathi Faris Omar, "I am not saying that all citizen journalists are unreliable, there are some who are well-informed who have a lot of followers, even more than real journalists (professional journalists)".

Lau Chak Onn noted that the two-way communication between citizen journalists and their readers (and other citizen journalists) assisted in forming a much precised and accurate citizen journalism content. He said,

Just as citizen journalists can post what they feel is true and right, other users are just as free to feedback and critique. So, while there isn't necessarily accuracy the first time around, there is a pretty effective corrective mechanism among citizen journalists.

Most of the informants also said that the availability of varied content provides an opportunity for people to make informed choices, especially in politics. Clare Rewcastle Brown stated,

If the government stops the people from accessing information, they (government) eventually stop the intellectual growth of the civil society. By restricting them (the citizens) to access only certain information ... is a way to express, umm, that the people are not smart enough to distinguish between the good and the bad. Malaysians, like you, should have access to variation of info, this allow you to make informed decisions, especially when it comes to politics.

The reports generated by citizen journalists are thought to play an important "checkand-balance" role to contrast with the reports produced by the mainstream media. Since the mainstream media are perceived as biased and used as the government's 
propaganda tool, alternative viewpoints provided by citizen journalists allow people a wider context on issues happening in the country. "Citizen journalism can also act as 'check and balance' before coming to a solution (making a decision)," said Rosey Haji Yunos.

\section{Citizen Journalism as a Double-Edged Sword}

\section{Low-quality content, fake news and misinformation}

Although the informants agreed that citizen journalism widens the domain of discourse and provides alternative views on events happening in the world, they all stressed several problems with citizen journalism. They generally agreed that one effect of the lack of journalism training was generally low-quality content. Many, if not most, of the reports are heavily influenced by the citizen journalists' personal opinions on the matter reported, especially when the content relates to political issues.

The main issues pertained to authenticity, credibility and accountability. In general, most informants were skeptical of authenticity in citizen journalism. They noted that an abundance of fake news and misinformation can be easily found on the internet. Lack of research, especially in corroborating facts and the influence of personal bias in content creation often mean citizen journalists are perceived as less credible than professional ones. Fathi Aris Omar noted, for example,

Although citizen journalism has the power to provide media audiences with alternative content $\ldots$ these reports, however, are not necessarily accurate. Abundance of misleading information can be found and further boosted by the popularity of social media and reaching the wider public.

He also noted the role played by such gatekeepers as editors to oversee reports produced by citizen journalists. He said,

The absence of gatekeepers like editors to double-check their (citizen journalists') facts, and the authenticity of their reports, we can't deny has contributed to the low-quality content. Not only that, these (citizen) journalists also love to compete with other users on who's reporting on events quicker than the others.

He further noted that in the absence of gatekeepers, misinformation could easily be shared and sensitive issues could be played to the extent of threatening national security. Nurul Izzah Anwar noted the importance of corroborating facts, 
But most importantly, the perspectives - irrespective of one's capacity as a citizen journalist or a professional journalist - that one conveys must always be grounded in facts. Glenn Greenwald is the US journalist who broke the news of NSA's violations together with Edward Snowden, who I had the privilege of speaking to during an interview with AlJazeera. I share Greenwald's sentiment that no journalism-from the most stylistically "objective" to the most brazenly opinionated-has any real value unless it is grounded in facts, evidence and verifiable data. The claim that overtly opinionated journalists cannot produce good journalism is every bit as invalid as the claim that the contrived form of perspective-free journalism cannot.

Lau Chak Onn also highlighted the issue of credibility when he noted that citizen journalists might not have the same motivation as professional journalists in terms of willingness to investigate before publishing reports. He stressed that citizen journalists could be motivated by reasons other than being real news reporters. He stated,

I don't think (that) the average person is interested enough to investigate something fairly and in-depth. At the end of the day, all humans are motivated by different things ... need to be famous or rich should never play into a journalist's mind ${ }^{3}$, but unfortunately, the average person would be at least partially motivated by these things.

Another common view shared by the research informants was the likelihood of citizen journalism content to be skewed by personal bias, especially when it comes to political issues. "Due to the nature of citizen content journalism, which thrives on social media networking, the degree of biased or skewed material exists, which may compromise the integrity of the information content compared to professional media", said Ibdillah Ishak. Some informants noted that citizen journalism content could be unnecessarily contentious and emotional. "Citizen journalists are more emotional, and their opinion based merely on personal perception and judgement. Thus, it can create misunderstanding in the content", said Rosey Haji Yunos.

\section{Minimal effect on political literacy}

Another common thread found among the various narratives of the informants was skepticism about citizen journalism content having a positive impact on political literacy. The questionable quality of such content and the high possibility of fake news being dispersed in the virtual domain, led most informants to believe there are great possibilities for citizen journalism content to negatively affect political literacy. Fathi Faris Omar, for example, asserted that, 
In an ideal world where all people have the courtesy to practice good journalism (conduct in-depth research before reporting news and being objective without bias in news production), citizen journalism could have a positive impact on political literacy. However, what we see on social media, for example the posts (reports), are not reliable, sometimes, pure nonsense.

Nurul Izzah shared a similar view,

Citizen journalism is borne out of new media sites where people can easily express themselves. But, having low barriers of entry to expressing oneself is not necessarily a precursor of political literacy of others. For example, in the US, where freedom of expression is paramount, new media sites are more than common, but many are still not politically literate. According to a 2015 study by Pew Research Centre, millennials are less interested in politics and governance than the older generation despite the fact that the millennials are the most prolific users of new media sites.

The informants did not deny the possibility of internet users, particularly social media users, becoming more politically informed because of the content and information they read online. However, due to the nature of social media, internet users tend to produce short articles providing only brief information on political events - which can misguide audiences by failing to provide the full context of the issue. Lau Chak Onn, stressing the features of Twitter, one of the leading social media, said, "Through 140-character long tweets or brief Facebook posts, citizen journalism is certainly limited in publishing thoroughly studied and corroborated claims".

Nurul Izzah also noted that the users of social media sites can easily find news of current affairs and political news while surfing the sites, and there are possibilities for them to be more politically informed. However, the reports usually shared online are compact and short, so understanding the political issues could be limited. Further efforts should be made for deeper understanding of political issues. Nurul Izzah said,

Because of the inevitability of stumbling upon current affairs and political news while using social media, one may become more politically informed. But consuming bite-sized information now and then only constitutes shallow reading. That doesn't make one politically literate. To be so requires a deeper level of engagement - in-depth reading on politics and governance, conversations on the subject and self-reflection on one's political values. 
Another informant, Marina Mahathir, noted that the digital divide could also affect political knowledge. She asserted that lack of media literacy is another type of digital divide in Malaysia beyond the lack of communication structures in certain parts of the country. She posited that despite over $70 \%$ of the people having access to the internet and varied content that could increase their knowledge on politics, the lack of media literacy means internet users tend to believe what they read online without checking the authenticity of the news. "Millions of internet users are creating content online on a daily basis, the lack of skill in researching the plausibility of the reports they read indicates the low media awareness among Malaysians", said Marina Mahathir. Instead of contrasting content from different sources to check facts, most Malaysians were criticised as lazy, reading only one news source. Marina Mahathir continued,

The digital divide isn't only structural, like when you talk about the rural-city digital divide. Media literacy is also a digital divide. Those who are low in this literacy tend to believe content they read online without checking other sources to check whether the information they read is correct or not. The lack of media literacy also leads the reporters (citizen journalists) to generate incorrect news and could make the readers become angry and then participate in political events for the wrong reasons.

Ibdillah Ishak stressed the importance of media literacy. He said,

Political literacy in Malaysia is still at its minimal level but increasing at a rapid pace, due to the development of communication technology and borderless information flow. However, the lack of media literacy may hinder and cause speculations. This leads to the failure to understand government's propositions. A better understanding of Malaysia's political ecosystem is vital, to ensure higher political literacy.

\section{Persuasive citizen journalism content, public opinion, and political participation}

Another repetitive theme found in the interview sessions was the informants' opinions on the potential of persuasive content to influence political participation. All the informants agreed that convincing content on the internet would have the power to affect political participation. Informants frequently emphasised the use of social media during the The Coalition for Clean and Fair Elections (BERSIH) rallies in Malaysia. The rally goers were believed to be using news reports generated by citizen journalists, especially on Twitter, to update themselves on the progress of events in different locations and on the whereabouts of the authorities. Clare Rewcastle Brown said, 
Again, if you ask my opinion on whether or not citizen journalism could impact political participation in Malaysia, of course, I think it does have its power. Content shared by people on Facebook, for example during BERSIH, contributed to the large turnouts during the rally. I was there (BERSIH rally in London), umm, they asked me to comment ... I think the whole movement shows that there is some degree of influence brought by content generated by the citizens.

The same view was shared by Nurul Izzah Anwar,

Citizen journalism affects participation to a certain extent. The recent BERSIH 3.0 and 4.0 happened during an era when new media sites were prevalent, and both saw record numbers of participants. Neither event was deemed as savory (good) by the government and both were thus mostly discussed on and promoted through new media sites. And this achieved great success. For BERSIH 4.0 in particular, reportage from citizens on the first day of the event contributed to additional people showing their support the next day.

She also stressed the influence of citizen journalism content towards shaping public opinion. Other informants, including Ibdillah Ishak, echoed the same notion. He said,

Citizen journalism or any alternative journalism is used to achieve certain pre-fixed (planned) objectives, which I think have been set to assist in invoking higher political will and participation. Undeniably, the social media and its content shape public opinion including on political issues.

Some of the informants highlighted the possibility that content uploaded by citizen journalists could have a negative effect on political participation. Some noted cases in which people refused to participate in political activities as a result of constantly reading contentious news reports online. Although multiple factors contribute to refusing to participate, the informants noted the possibility that people are becoming too intimidated by the citizen journalism reports they read online to participate. For example, Marina Mahathir briefly noted that there were a number of articles published by citizen journalists on BERSIH rallies, framing the event in a negative light (rally goers were apprehended and potential punishment by the government) making people reluctant to participate. Another potential reason is that people are tired of reading often-controversial political news which causes them to withdraw from participating in politics. As Fathi Aris Omar said,

Citizen journalism can also have a reverse impact on political participation, you know. Some readers constantly read all these controversial reports generated by other people, though most are just 
unverified news, and became scared and intimidated by possible punishments they could receive if they actively participate. But there are also people who, I think, are just fed-up (tired) with this political news and scandals that they just chose to ignore everything.

Some informants made the point that convincing content found on the internet is not necessarily accurate. Inaccurate and contentious content could lead to formation of aggressive political campaigns fueled by rage, with the potential to jeopardise national harmony. Another point made by the informants was that despite increasing participation in politics among Malaysians, changes in the Malaysian political arena will take time. Marina Mahathir said,

Participation is increasing, of course, but the changes won't happen overnight. There are other causes that we have to put into consideration. The set of laws by the government, lack of political literacy among the younger generation, and our people in general could also hinder the progress.

She urged Malaysians to actively engage in political activities to push for better democracy in the country.

\section{CONCLUSION}

After reviewing the informants' responses, it was found that citizen journalism to a certain degree does influence the Malaysian political landscape. It plays a role in assisting Malaysian political transformation. Like many other activities done online, citizen journalism is an example of how Malaysians practice democracy, through generating their news content with less scrutiny by gatekeepers. Unlike mainstream media, the internet offers great liberty for its users to bypass state control. According to the informants, however, changes to the political landscape will not happen overnight. It will take active participation in political discourse (including citizen journalism), continuously expressing opinions on politics through the internet and regular involvement in partisan activities. Since the interview sessions in 2016, political discourse has become more active on social media as the election approached. Pressure on political parties was fueled by conversations on social media and led to the first election upset in Malaysian history (Najwa and Amalina 2018; Chu 2018). Digital democracy is becoming even more vital in the current world, and governments across the globe have to acknowledge that digital democracy (or e-democracy) is becoming a mainstream trend among the citizens.

Based on the responses received, changes in the Malaysian political domain are also affected by the Malaysian political setting, legal framework and literacy 
levels among Malaysians. With the semi-democratic setting in Malaysia and the laws established to control freedom of speech, political progress is expected to be gradual. Raja Petra Kamaruddin of Malaysia Today, for example, noted that despite over two decades since introduction of the internet and the use of online platforms for political engagements, only small changes ${ }^{4}$ can be seen in Malaysia's political arena. The rigid political framework in the country and the long-lasting governance by Barisan Nasional have been a challenge to significant transformations in politics. The use of colonial laws to restrict freedom of expressions is another structural hurdle for political metamorphosis in Malaysia. Raja Petra also noted that despite gradual changes, general elections in Malaysia has been impacted by the internet. During the 2008 and 2013 general elections, Barisan Nasional has lost its majority in the parliament (Fee and Appudurai 2011; Mohd Azizuddin and Zengeni 2010; Willnatet al. 2013; Mohd Azizuddin 2014). This gradual change shows that the influence of social media will need time to transform the political landscape in Malaysia. In 2018, it finally reached its zenith when the Pakatan Harapan coalition won a majority of seats in the parliament.

The interaction with informants has shown that citizen journalism is one way to practice democracy, with citizens freely expressing their opinions on politics and sharing information on critical issues in Malaysia. Although citizen journalism has been criticised for providing a narrow view on political issues, it is deemed essential in presenting alternative perspectives on politics - providing Malaysians with the opportunity to form better opinions on political issues, as well as offering them the chance to make informed decisions on politics. Citizen journalism content is also important in providing "check-and-balance" against content shared through mainstream media. The practice of contrasting information from various sources is pivotal in forming opinions (and making decisions) as well as to corroborating the legitimacy of the content. Though highlighting the positive attributes of citizen journalism, some of the informants were skeptical of the practice itself. Citizen journalism content is a double-edged sword, which could have both positive and negative impacts on the country. Some of the informants emphasised the lack of depth in citizen journalism content fails to provide a wider context to the political news, leading to tunnel vision on political issues and widespread misguided political propaganda.

Most citizen journalism content is perceived as heavily influenced by citizen reporters' personal opinions - risking the credibility of the material. An ethical issue most frequently cited by informants; the reliability of citizen journalism content includes concern for the accuracy of information. Many citizen reporters lack training in conducting in-depth research before reporting news and personal agendas influence their media content. Another concern about citizen journalism is the authenticity of the material. With fake news spread wide online, not only in Malaysia but across the world, some informants were skeptical of 
citizen journalism. Lack of such gatekeepers as editors to check content before distribution is deemed a major factor contributing to distribution of inaccurate information on the internet. The popularity of Facebook, Twitter and WhatsApp among others was a potential factor in the wide distribution of fake news. With the high interactivity on social media, sharing of misleading information between users happens very quickly. Some informants blamed citizen reporters for lacking a sense of responsibility for the content they generate and share as another worrying aspect of citizen journalism. The ability to hide user identity on internet platforms is misused by irresponsible individuals to distribute deceptive content. Low literacy among Malaysians in both media ${ }^{5}$ and politics makes the online sphere an optimum setting for the spread of misleading news. The abundance of false information on the web indirectly impacts Malaysians' political knowledge if they fail to corroborate what they read on the internet.

Some of the informants emphasised the power of persuasive citizen journalism content to influence political participation. Ibdillah Ishak among others, stressed that some citizen reporters use social media to persuade Malaysians to participate in politics. The study informants often highlighted the use of social media during BERSIH campaigns. While some citizen journalism content could lead to more political engagement among citizens, some of their other content, especially contentious political news, could result in political disengagement. Fathi Faris Omar of MalayMail Online asserted that such content could intimidate Malaysians into not participating in politics or to abandon political activities altogether as they wearied of controversial political news.

As a conclusion, based on the themes, informants posited that citizen journalism does influence Malaysian politics, although the changes happen gradually over time. This can be seen in the transition in the Malaysian political scene from the general election in 2008. Barisan Nasional for the first time lost its two-thirds majority in the parliament (Mohd Azizuddin 2014) and in 2018 its political nemesis, Pakatan Harapan replaced them. This finding echo other research by scholars such as Syed Arabi (2018) - that despite social media having become a valuable domain, users doubt the reliability of the content due to various factors. Furthermore, criticism of citizen journalism, particularly its accountability and quality of content, indicates it needs to be improved as an alternative information source for contemporary audiences. With the changing nature of journalism, citizen participation in content generation is inevitable, especially with the advancement of communication technologies. Responsible citizen reporting will not only assist in widening democracy in Malaysia, it will also be a check-andbalance mechanism in the skewed Malaysian media environment. As for political participation, responsible reporting by citizen journalists will help maintain public order. Irresponsible fake news reporting playing on racial elements, for example, will lead to disruption and threaten national security. Overall, this research found 
that citizen journalism does influence the Malaysian political landscape as one of the tools for the democratisation of Malaysia. This data was gathered from the perspective of a few selected individuals. Interested scholars could study the issue through the lens of citizen journalists who are active on social media. This would balance the data from this research which be interpreted as biased towards established reporters and political figures.

\section{NOTES}

1. Usually involving pop-up ads and side banners. The hosts of such blogs or websites (i.e., citizen reporters) "rent" space on their websites for interested parties to advertise services or products.

2. In the practice of citizen journalism through the internet, the absence of gatekeepers not only provides citizen reporters with more liberty for content creation, but it also allows them to bypass government scrutiny as the internet has more freedom than the mainstream media space does.

3. Lau Chak Onn was referring to some irresponsible citizen reporters who produced content using "click bait" headlines with the intent of having the story go viral in order to generate money (personal communication, 17 August 2016).

4. Raja Petra noted that the opposition parties and critics had been using the internet for their political causes, but no major changes in politics could be seen. However, he noted that there is progress towards a more democratic space in Malaysia even though the pace is slow (personal communication, 28 April 2017).

5. According to some informants like Marina Mahathir, low media literacy among Malaysians is evident in the failure to distinguish between real and fake news, rather than the inability to conduct further research to corroborate information read online (personal communication, 28 July 2016).

\section{REFERENCES}

Abbott, J. 2014. Hype or hubris? In Routledge handbook of Southeast Asian democratization, ed. W. Case, 201. London: Routledge.

Abbott, J.P. 2001. Democracy@internet.asia? The challenges to the emancipatory potential of the net: Lessons from China and Malaysia. Third World Quarterly 22(1): 99-114. https://doi.org/10.1080/01436590020022600

Albarado, S. 2012. Citizen journalism. Encyclopedia Britanica. https://www.britannica .com/topic/citizen-journalism (accessed 16 April 2017).

Allan, S. and E. Thorsen, eds. 2009. Citizen journalism: Global perspectives. New York: Peter Lang.

Baker, V. 2015. How far can you trust citizen journalism on the internet? Newstatesman. 25 March. http://www.newstatesman.com/media/2015/03/how-far-can-you-trustcitizen-journalism-internet (accessed 16 April 2017). 
Beard, F. and R.L. Olsen. 1999. Webmasters as mass media gatekeeprs: A qualitative exploratory study. Internet Research 9(3): 200-211. https://doi .org/10.1108/10662249910274601

Bowman, S. and C. Willis. 2003. We media: How audiences are shaping the future of news and information. Reston, VA: The Media Center at The American Press Institute.

Braun, V. and V. Clarke. 2006. Using thematic analysis in psychology. Qualitative Research in Psychology 3(2): 77-101. https://doi.org/10.1191/1478088706qp063oa

Case, W. 2004a. Testing Malaysia's pseudo-democracy. In The state of Malaysia: Ethnicity, equity and reform, eds. S.K. Mandal and E.T. Gomez, 29-48. London: Routledge. 2004b. New uncertainties for an old pseudo-democracy: The case of Malaysia. Comparative Politics 37(1): 83-104. https://doi.org/10.2307/4150125

Chadha, K. and L. Steiner. 2015. The potential and limitations of citizen journalism initiatives: Chhattisgarh's CGNet Swara. Journalism Studies 16(5): 706-718. https://doi.org/10.1080/1461670X.2015.1054179

Channel, A. 2010. Gatekeeping and citizen journalism: A qualitative examination of participatory newsgathering. Master's diss., University of South Florida. http://scholarcommons.usf.edu/cgi/viewcontent.cgi? article=2597\&context=etd (accessed 18 March 2017).

Chin, J. 2014. Pseudo-democracy and the making of a Malay-Islamic state. In Routledge Handbook of Southeast Asian Democratization, ed. W. Case, 399-409. London and New York: Routledge.

Chu, M.M. 2018. Big data and the big day: Tech's effect on GE14. The Star. 9 May. https://www.thestar.com.my/news/nation/2018/05/09/big-data-and-the-big-daytechs-effect-on-ge14/ (accessed 2 July 2018).

Couldry, N. and J. Curran, eds. 2003. Contesting media power: Alternative media in a networked world. Maryland: Rowman \& Littlefield Publishers.

DeMers, J. 2013. How social media is supporting a fundamental shift in journalism. Huffpost. 5 August. http://www.huffingtonpost.com/jayson-demers/how-socialmedia-is-suppo_b_3239076.html (accessed 18 September 2017).

Dredge, S. 2014. Social media, journalism and wars: 'Authenticity has replaced authority'. The Guardian. 5 November. https://www.theguardian.com/technology/2014/ nov/05/social-media-journalism-wars-authenticity (accessed 21 September 2016).

Fee, L.K. and J. Appudurai. 2011. Race, class and politics in Peninsular Malaysia: The general election of 2008. Asian Studies Review 35(1): 63-82. https://doi.org/10.1 080/10357823.2011.552706

Freedom House. 2018. Freedom of the world 2018: Malaysia profile. https://freedomhouse. org/report/freedom-world/2018/malaysia (accessed 2 July 2018).

Gillmor, D. 2006. We the media: Grassroots journalism by the people, for the people. California: O’Reilly Media, Inc.

Jurrat, N. 2012. Mapping digital media: Citizen journalism and the internet. United Kingdom: Open Society Foundations. https://www.opensocietyfoundations. org/sites/default/files/mapping-digital-media-citizen-journalism-andinternet-20110712.pdf (accessed 15 June 2016). 
Kovach, B., and T. Rosenstiel. 1999. Warp speed: America in the age of mixed media. New York: Century Foundation.

Krotoski, A. 2011. What effect has the internet had on journalism? The Guardian. 20 February. https://www.theguardian.com/technology/2011/feb/20/what-effectinternet-on-journalism (accessed 16 November 2016).

Lee, R. 2016. Malaysians are leading the world in social media and mobile. SoyaCincau. 5 May. http://www.soyacincau.com/2016/05/05/malaysians-are-leading-theworld-in-social-media-and-mobile/ (accessed 27 June 2017).

Lewis, S.C., K. Kaufhold and D.L. Lasorsa. 2010. Thinking about citizen journalism: The philosophical and practical challenges of user-generated content for community newspapers. Journalism Practice 4(2): 163-179. https://doi.org/10 $.1080 / 14616700903156919$

Lieb, T. 2009. All the news: Writing and reporting for convergent media. Boston: Pearson/ Allyn \& Bacon.

Lindlof, T.R. and B.C. Taylor. 2017. Qualitative communication research methods. London: Sage.

Media Rakyat. 2017. About media rakyat. http://mediarakyat.net/ (accessed 21 December 2017).

Mernon P. and J. Chalmers. 2016. Malaysia's sacked deputy warns of election defeat unless PM goes. Reuters. 20 April. https://www.reuters.com/article/us-malaysiascandal-muhyiddin/malaysias-sacked-deputy-warns-of-election-defeat-unlesspm-goes-idUSKCN0XH18Y (accessed 21 December 2017).

Mohd Azizuddin Mohd Sani. 2014. The social media election in Malaysia: The 13th general election in 2013. Kajian Malaysia 32(Supp.2): 123-147. https://doi. org/10.1111/aspp. 12410

2018. Battle royale on social media in the 2018 general election in Malaysia. Asian Politics \& Policy 10(3): 556-560.

Mohd Azizuddin Mohd Sani and K.T. Zengeni. 2010. Democratisation in Malaysia: The impact of social media in the 2008 general election. Paper presented at the Asian Studies Association of Australia (ASAA) 18th Biennial Conference, The University of Adelaide, Australia. 5-8 July.

Najwa Abdullah and Amalina Anuar. 2018. Old politics and new media: Social media and Malaysia's 2018 elections. The Diplomat. 8 May. https://thediplomat. com/2018/05/old-politics-and-new-media-social-media-and-malaysias-2018elections/(accessed 13 June 2018).

Phillips, T. 2009. Citizen journalism isn't always a good thing. Research Live. 1 October. https:/www.research-live.com/article/opinion/citizen-journalism-isnt-always-agood-thing/id/4001064 (accessed 14 November 2016).

Reich, Z. 2008. How citizens create news stories: The 'news access' problem reversed. Journalism Studies 9(5): 739-758. https://doi.org/10.1080/14616700802207748

Rosen, J. 2008. A most useful definition of citizen journalism. NYU Journalism. http://journalism.nyu.edu/pubzone/weblogs/pressthink/2008/07/14/a_most_ usefuld.html (accessed on 15 June 2016). 
Saravanamuttu, J. 2008. Malaysian politics. In March 8: Eclipsing May 13, eds. O.K. Beng, J. Saravanamuttu and L.H. Guan, 33. Singapore: Institute of Southeast Asian Studies.

Schudson, M. 2003. The sociology of news, contemporary societies. New York: Norton.

Seneviratne, K. 2008. Citizen journalism need not be anti-government. (Paper in themed articles: Citizen journalism, ed. B. Michael). Australian Journalism Review 30(2): $85-93$.

Singer J. 2006. The socially responsible existentialist: A normative emphasis for journalists in a new media environment. Journalism Studies 7(1): 2-18. https://doi.org/10.1080/14616700500450277

Slater, D. 2003. Iron cage in an iron fist: Authoritarian institutions and the personalization of power in Malaysia. Comparative Politics, 81-101. https://doi .org/10.2307/4150161

Socialbakers. 2016. Facebook statistics directory. https:/www.socialbakers.com/statistics/ facebook/ (accessed 23 July 2017).

Syed Arabi Idid. 2018. The Malaysian 14th general election: Media use and trust among party supporters. Forum on "Media and Communications ahead of the 14th general election", Kuala Lumpur. 5 April.

Tan, J.E. and Zawawi Ibrahim. 2008. Blogging and democratization in Malaysia: A new civil society in the making. Selangor: Strategic Information and Research Development Centre.

Telekom Malaysia. 2018a. Unifi plans. https://unifi.com.my/personal/home/fibrebroadband (accessed 12 February 2018).

.2018b. Streamyx broadband plans. https://unifi.com.my/personal/home/broadband (accessed 12 February 2018).

Thompson, M.R. 1993. The limits of democratisation in ASEAN. Third World Quarterly 14(3): 469-484. https://doi.org/10.1080/01436599308420338

TIME. 2018. Time Fibre Broadband Malaysia. https://www.time.com.my/personal/ broadband/fibre-broadband (accessed 12 February 2018).

Volpi, F. 2004. Pseudo-democracy in the Muslim world. Third World Quarterly 25(6): 1061-1078. https://doi.org/10.1080/0143659042000256896

Weiss, M.L. 2006. Protest and possibilities: Civil society and coalitions for political change in Malaysia. California: Stanford University Press. 2009. Edging toward a new politics in Malaysia: Civil society at the gate? Asian Survey 49(5): 741-758. https://doi.org/10.1525/as.2009.49.5.741

Willnat, L., W.J. Wong, E. Tamam and A. Aw. 2013. Online media and political participation: The case of Malaysia. Mass Communication and Society 16(4): 557-585. https://doi.org/10.1080/15205436.2012.734891 